"Coppice forests: past, present and future"

Editors: Tomas Vrska, Renzo Motta, Alex Mosseler

\title{
Thinning effects on soil and microbial respiration in a coppice- originated Carpinus betulus L. stand in Turkey
}

\section{Serdar Akburak, Ender Makineci}

\section{Introduction}

Accumulation and distribution of the soil carbon pools in forest ecosystems play a crucial role in the carbon cycle of terrestrial ecosystems and climate change, and underground ecological processes critically affect and regulate global soil carbon cycle dynamics (Wu et al. 2013). Soil respiration is one of the main terrestrial contributors to $\mathrm{CO}_{2}$ fluxes in the global carbon cycle (Gong et al. 2014). Thus, knowledge about soil respiration (both heterotrophic and autotrophic) is important for understanding ter-

\begin{abstract}
Effects of thinning on soil respiration and microbial respiration were examined over a 2-year period (2010-2012) in a coppice-originated European hornbeam (Carpinus betulus L.) stand in Istanbul, Turkey. Four plots within the stand were selected; tree density was reduced by $50 \%$ of the basal area in two plots (thinning treatment), and the other two plots served as controls. The study focused on the main factors that affect soil respiration $\left(R_{s}\right)$ and microbial respiration on the forest floor $\left(R_{F F M}\right)$ and in soil $\left(R_{S M}\right)$ : soil temperature $\left(T_{S}\right)$, soil moisture $\left(M_{s}\right)$, soil carbon $(C)$, soil nitrogen $(N)$, soil $p H$, ground cover biomass (GC), forest floor mass (FF), forest floor carbon (FFC) and nitrogen (FFN), and fine root biomass (FRB). Every 2 months, soil respiration was measured using the soda-lime method, and microbial respiration was measured with the incubation method separately for the soil and forest floor. Results were evaluated yearly and over the 2-year research period. During the first year after treatment, $R_{\mathrm{s}}$ was significantly higher $(11 \%)$ in the thinned plots $\left(1.76 \mathrm{~g} \mathrm{C} \mathrm{m}^{-2} \mathrm{~d}^{-1}\right)$ than in the controls $\left(1.59 \mathrm{~g} \mathrm{C} \mathrm{m}^{-2} \mathrm{~d}^{-1}\right)$. However, there were no significant differences in either the second year or the 2-year study period. In the thinned plots during the research period, $R_{s}$ was linearly correlated with $G C, T_{s}$ and FRB. Thinning treatments did not affect $R_{S M}$, but interestingly, they did affect $\mathbf{R}_{\mathrm{FFM}}$, which was greater in the control plots than in the thinned plots. $\mathbf{R}_{S M}$ had a significant and positive correlation with soil $\mathrm{N}$ and soil $\mathrm{pH}$, while $\mathrm{R}_{\mathrm{FFM}}$ was linearly correlated with FFC and $\mathrm{C} / \mathrm{N}$ ratio of the forest floor in both thinned and control plots during the research period.
\end{abstract}

Keywords: $\mathrm{CO}_{2}$ Flux, Fine Root, Forest Floor, Ground Cover, Soil Temperature, Soil Moisture

restrial C cycling and feedback with regard to climate change (Fu et al. 2013).

In addition to temporal and spatial changes based on natural factors, forest operations can affect soil respiration and soil carbon pools. Understanding the effects of forest treatments on forest ecosystems is critical for estimating temporal carbon dynamics (Ryu et al. 2009). The consequences of forestry practices on $\mathrm{C}$ balances and $\mathrm{CO}_{2}$ emissions from the soil are still poorly understood in terms of their impact on global C flux.

$\square$ Istanbul University, Faculty of Forestry, Soil Science and Ecology Department, 34473 Bahcekoy, Sariyer, Istanbul (Turkey)

@ Ender Makineci (emak@istanbul.edu.tr)

Received: Aug 12, 2015 - Accepted: Apr 04, 2016

Citation: Akburak S, Makineci E (2016). Thinning effects on soil and microbial respiration in a coppice-originated Carpinus betulus L. stand in Turkey. iForest 9: 783-790. - doi: 10.3832/ifor1810-009 [online 2016-05-29]

Forest thinning affects soil processes by altering key microclimatic conditions, root and microbial respiration, soil organic matter turnover and $\mathrm{N}$ mineralization rates (Tang et al. 2005, Olajuyigbe et al. 2012, Alvarez et al. 2014). Thinning and its variants (i.e., type, intensity, timing and interactions with other forest practices) can affect soil respiration (Cheng et al. 2014). Ryu et al. (2009) reported increased soil respiration and microbial respiration based on how much soil temperature and moisture rose; however, fine root biomass decreased after thinning treatments. Similarly, Tian et al. (2010) found that soil respiration increased quickly in the first period after thinning but declined afterwards. In contrast, Campbell et al. (2009) and Vesala et al. (2005) reported that thinning had no important effect on soil respiration. These contradictory results show that the effects of thinning on the carbon balance of forests are still poorly understood (Campbell et al. 2012, Dore et al. 2012).

European Hornbeam (Carpinus betulus L.) is an important deciduous species that covers 19,962 ha in Turkey, accounting for $0.1 \%$ of the country's forests (OGM 2014). The 
hornbeam forest featured in the current study was originally coppiced, a management practice with a long history in Turkey. However, traditional coppice management has been mostly abandoned, and former coppice forests were converted to high forest following the decision of the Turkish General Directorate of Forestry in 2006. Old root systems, rapid and fast-growing resprouts, and intensive management with former clear-cuts may produce intrinsic variability in these forest ecosystems, affecting the vegetation cover, litterfall, quality and quantity of forest floor, soil organic matter and biological characteristics of forest floor and soil (Makineci et al. 2015).

The main objectives of the present study were: (1) to investigate the effects of thinning on soil respiration and microbial respiration in the forest floor and soil; (2) to determine temporal changes in the main factors influencing soil and microbial respiration (soil temperature, soil moisture, fine root biomass, ground cover, forest floor, soil acidity, soil carbon, soil nitrogen, forest floor carbon, forest floor nitrogen); and (3) to evaluate the correlations of the investigated factors with soil and microbial respiration over a 2-year time frame.

\section{Material and methods}

\section{Study site}

The study was conducted in the Education and Research Forest of the Faculty of Forestry at Istanbul University, located in Istanbul province, Turkey ( $41^{\circ}$ o9' $15^{\prime \prime}-41^{\circ}$ $\left.1^{\prime} 01^{\prime \prime} \mathrm{N} ; 28^{\circ} 59^{\prime} 17^{\prime \prime}-29^{\circ} 32^{\prime} 25^{\prime \prime} \mathrm{E}\right)$. The forest is at an altitude of $90 \mathrm{~m}$ a.s.l., the slope is $3 \%$ to $5 \%$, and the aspect is west-northwest. Long-term data indicate a maritime climate with medium water deficit in summer; the average annual precipitation is $1111.4 \mathrm{~mm}$, and the mean annual temperature is $12.7{ }^{\circ} \mathrm{C}$. The Luvisol (IUSS Working Group 2006) soils are well-drained, moderately deep and generally have a loamy clay texture (Akburak 2013).

Four sample plots were chosen, which included two areas that were thinned and two control areas $(50 \times 50 \mathrm{~m})$ in a coppiceoriginated pure European hornbeam stand. We determined the stand characteristics, including density, mean tree diameter and tree height of the sample plots (Tab. 1).

Tab. 1 - Main stand characteristics of the sample plots.

\begin{tabular}{lcc}
\hline Parameter & Control & Thinning \\
\hline $\begin{array}{l}\text { Density } \\
(\text { trees ha-1 }\end{array}$ & 1408 & 702 \\
\hline $\begin{array}{l}\text { Basal area } \\
\left(\mathrm{m}^{-2} \mathrm{ha}^{-1}\right)\end{array}$ & 26.2 & 13.0 \\
\hline $\begin{array}{l}\text { Mean tree } \\
\text { height }(\mathrm{m})\end{array}$ & 14.3 & 14.2 \\
\hline $\begin{array}{l}\text { Mean tree } \\
\text { diameter } \\
(\mathrm{DBH}, \mathrm{cm})\end{array}$ & 14.9 & 14.7 \\
\hline
\end{tabular}

Thinning was established by cutting $50 \%$ of the stand basal area. Sampling was confined to the central $25 \times 25 \mathrm{~m}$ area of each plot to reduce edge effects (Akburak 2013).

\section{Sampling and analysis of soil, forest floor, ground cover and fine root biomass}

Forest floor (FF) and ground cover (GC) were sampled from $0.25-\mathrm{m}^{2}$ quadrats in each plot. Forest floor was taken by collecting all the forest floor within the quadrat. After FF and GC samples were collected, steel soil cores $\left(100 \mathrm{~cm}^{3}\right)$ were used to collect soil samples from 0 to $10 \mathrm{~cm}$ of the mineral soil at the same points. Five FF, GC and soil samples were taken and bulked for each plot. All bulked or composite samples (forest floor and ground cover) were dried at $65{ }^{\circ} \mathrm{C}$ to constant weight and weighed. Soil samples were oven-dried at $105^{\circ} \mathrm{C}$ for $48 \mathrm{~h}$ and weighed, and the dry bulk density of the samples was calculated. Soil samples were then sieved with a 2-mm screen. Soil acidity $(\mathrm{pH}, 1 / 2.5 \mathrm{w} / \mathrm{v})$ was determined with a glass electrode digital $\mathrm{pH}$ meter $\left(\mathrm{HI} 221^{\oplus}\right.$, Hanna Instruments, Woonsocket, RI, USA). All samples were analyzed for their $\mathrm{C}$ and $\mathrm{N}$ concentrations by dry combustion (Akburak 2013) using a LECO CN-2000 analyzer ${ }^{\oplus}$ (LECO Co., St. Joseph, MI, USA).

The biomass of fine roots (FRB) was assessed by collecting five samples quarterly per plots from a depth of $35 \mathrm{~cm}$ by using steel soil cores (inner diameter $6.4 \mathrm{~cm}$ ). Roots were separated from the soil by gently washing them over a series of sieves with mesh sizes of $2.0 \mathrm{~mm}$. The fine roots were oven-dried at $65^{\circ} \mathrm{C}$ for $24 \mathrm{~h}$ and then weighed (Tufekcioglu et al. 2003).

\section{Measurement of soil respiration and microbial respiration}

Soil respiration $\left(R_{s}\right)$ was measured with the soda-lime method. In each plot, five sampling subplots and three sampling occasions (a total of 15 every two months) were chosen for a systematic sampling procedure. A plastic bucket with the same diameter as the soil respiration chambers was established at $1-\mathrm{cm}$ soil depth $24 \mathrm{~h}$ prior to any sampling. No live plant parts were inside the plastic bucket to avoid vegetation respiration. $\mathrm{CO}_{2}$ released from the soil inside the plastic bucket was absorbed by $60 \mathrm{~g}$ of granular (6-12 mesh) soda lime contained in jars that were $5 \mathrm{~cm}$ in diameter and $5 \mathrm{~cm}$ in height. Five blank jars were run to account for $\mathrm{CO}_{2}$ absorbance by soda lime during transportation, handling, and the opening and closing of the jars. Before and after each sampling period, the soda lime was oven-dried to constant weight at $105^{\circ} \mathrm{C}$. The mass gain of the soda lime during sampling was determined, and the area of the ground covered by the plastic bucket and the duration of the sampling period were then used to calculate the grams of $C$ released per square meter per day. Measurements were taken bimonthly from
October 2010 through October 2012 (Akburak 2013).

Soil temperature $\left(T_{\mathrm{s}}\right)$ at a depth of $0-5 \mathrm{~cm}$ was measured immediately adjacent to each soil respiration chamber. In addition, a cylindrical plug of soil $5 \mathrm{~cm}$ deep and $5 \mathrm{~cm}$ in diameter was collected and placed in an airtight metal tin. Stones, roots and litter were removed by hand, and the samples were weighed, oven-dried at $105{ }^{\circ} \mathrm{C}$, and finally reweighed to determine their gravimetric soil moisture content $\left(W_{\mathrm{s}}-\right.$ Akburak 2013).

Microbial respiration was determined by placing $30 \mathrm{~g}$ of soil (samples were adjusted to $50-55 \%$ water holding capacity) and $10 \mathrm{~g}$ of forest floor into 500-ml beakers, which were placed within sealed incubation vessels along with $10 \mathrm{ml}$ of $1 \mathrm{M} \mathrm{NaOH}$ and incubated in the dark at $25{ }^{\circ} \mathrm{C}$. The $\mathrm{CO}_{2}-\mathrm{C}$ evolved was measured every 7 days by adding $\mathrm{BaCl}_{2}$ and subsequently titrated with $1 \mathrm{M} \mathrm{HCl}$ (Alef \& Nannipieri 1995). Soil cores taken from each plot for microbial respiration measurements were used to calculate bulk density (<2-mm oven-dry mass per unit volume, which was defined as $g\left(\mathrm{~m}^{-2} \mathrm{~d}^{-1}-\right.$ Akburak 2013).

\section{Statistical Analysis}

Data were evaluated over four different periods: (1) 1-month results in October 2010 to show that none of the variables were significantly different before the treatment plots were thinned; (2) first year after thinning (2010-2011); (3) second year after thinning (2011-2012); and (4) the whole 2-year (2010-2012) research period. The results were subjected to $t$-test at the significance level of $a=0.05$ to identify statistically significant differences between the control and thinned plots within the research period (Akburak 2013).

Pearson's correlation analysis was used to determine the relationships between the dependent variables, which were soil respiration, soil microbial respiration and forest floor microbial respiration, and independent variables, which included soil carbon and nitrogen concentration, soil $\mathrm{pH}$, forest floor carbon and nitrogen concentration. The MiniTab ${ }^{\circledast} 16.0$ statistical software (MiniTab Inc., State College, PA, USA) was used for all statistical evaluations (Akburak 2013).

\section{Results}

\section{Effects of thinning on $R_{S}$}

Mean $R_{S}$ was determined to be between 0.45 and $3.18 \mathrm{~g} \mathrm{C} \mathrm{m}^{-2} \mathrm{~d}^{-1}$ in the thinned plots and ranged from 0.49 to $3.20 \mathrm{~g} \mathrm{C} \mathrm{m}^{-2} \mathrm{~d}^{-1}$ in the control plots. $R_{s}$ increased in all plots during the study period, especially in the autumn (Fig. 1). $R_{s}$ was significantly higher $(11 \%)$ in the thinned plots than in the control plots during the first year only. It did not differ significantly between the two types of plots in the second year or for the 2-year study period (2010-2012 - Tab. 2).

Temporal variation of $T_{s}$ was higher in the 
Fig. 1 - Seasonal variation of variables between thinning and control. Error bars represent the standard deviation. $\left(T_{s}\right)$ : soil temperature; $\left(M_{S}\right)$ : Soil moisture; $\left(R_{S}\right)$ : Soil respiration; (FRB): fine root biomass; (GC): ground cover; (FF): forest floor; (TA): thinning area; (CA): control area.
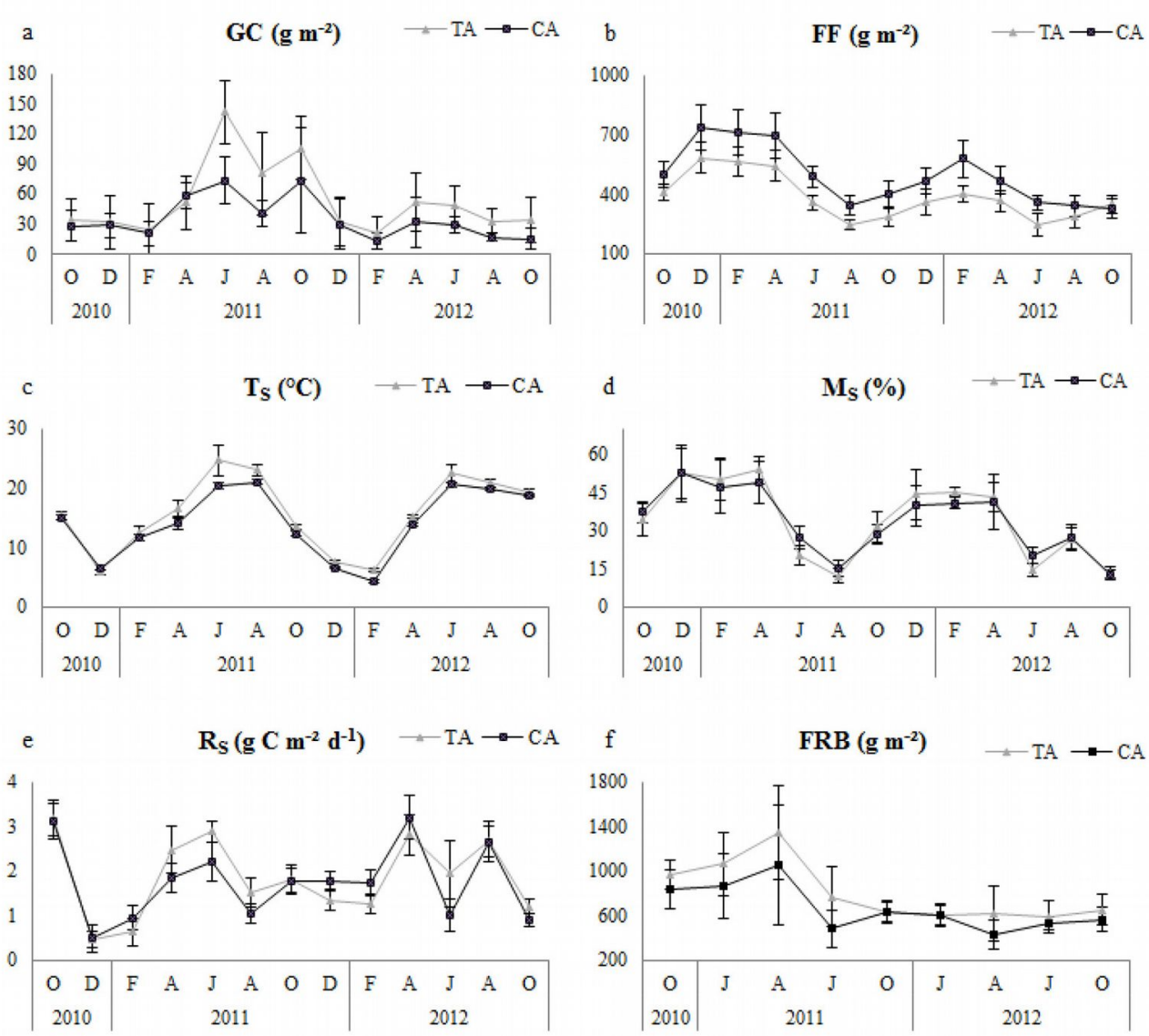

Tab. 2 - Means ( \pm standard deviation, STD) of the investigated parameters and results of the comparison between thinned and control plots (t-test, $a=0.05)$. (RS): soil respiration; (RSM): soil microbial respiration; (RFFM): forest floor microbial respiration; (FF): forest floor; (GC): ground cover; (TS): soil tempature; (MS): soil moisture; (FRB): fine root biomass; (FF N): forest floor nitrogen; (FFC): forest floor carbon; (FF C/N): forest floor C/N ratio; (TA): thinning area; (CA): control area.

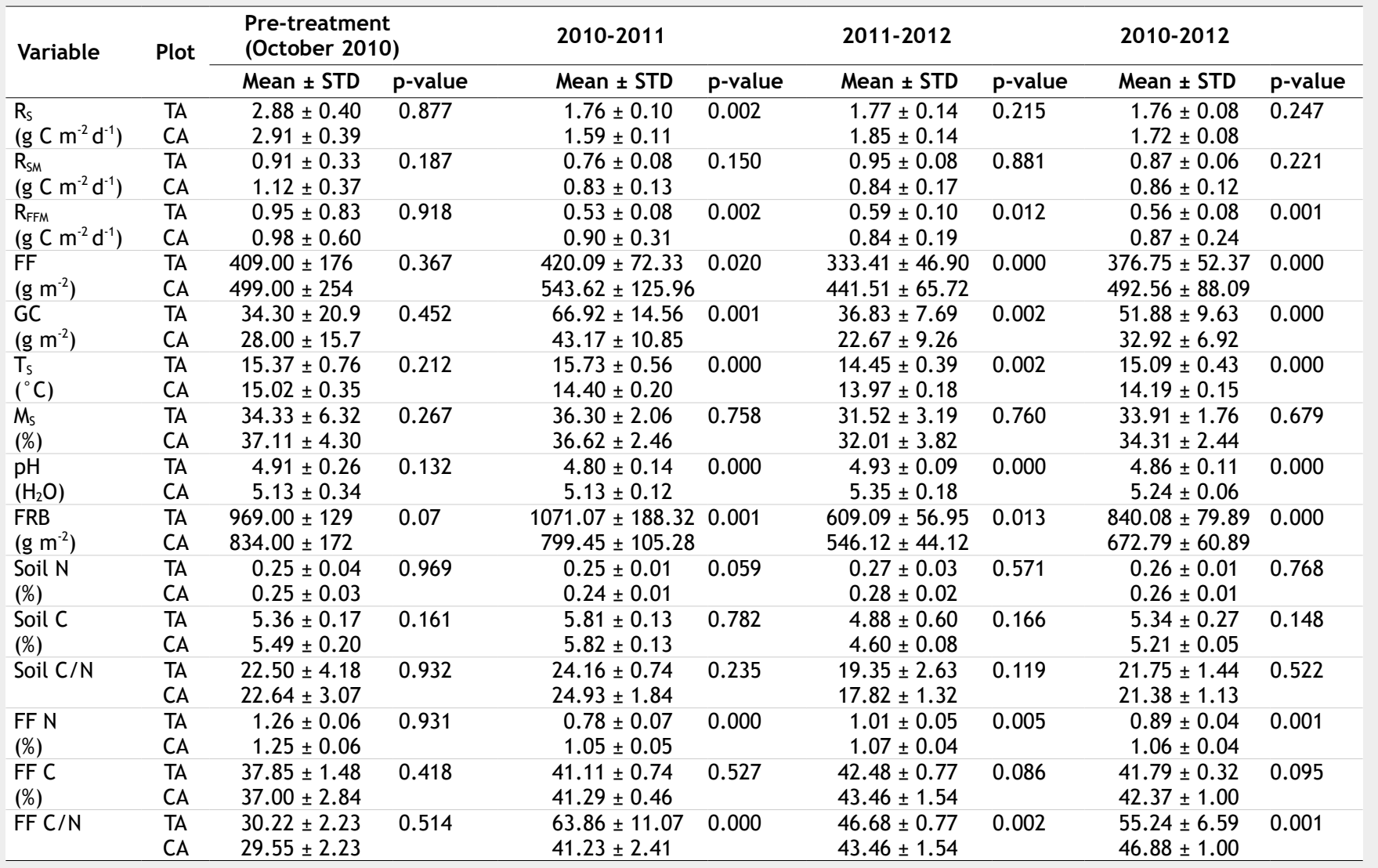


Fig. 2 - Temporal changes of soil microbial respiration

$\left(R_{S M}\right)$ and related variables in thinning and control plots.

Error bars represent the standard deviation. (Soil N) soil nitrogen; (Soil C): soil carbon; (TA): thinning area; (CA): control area.
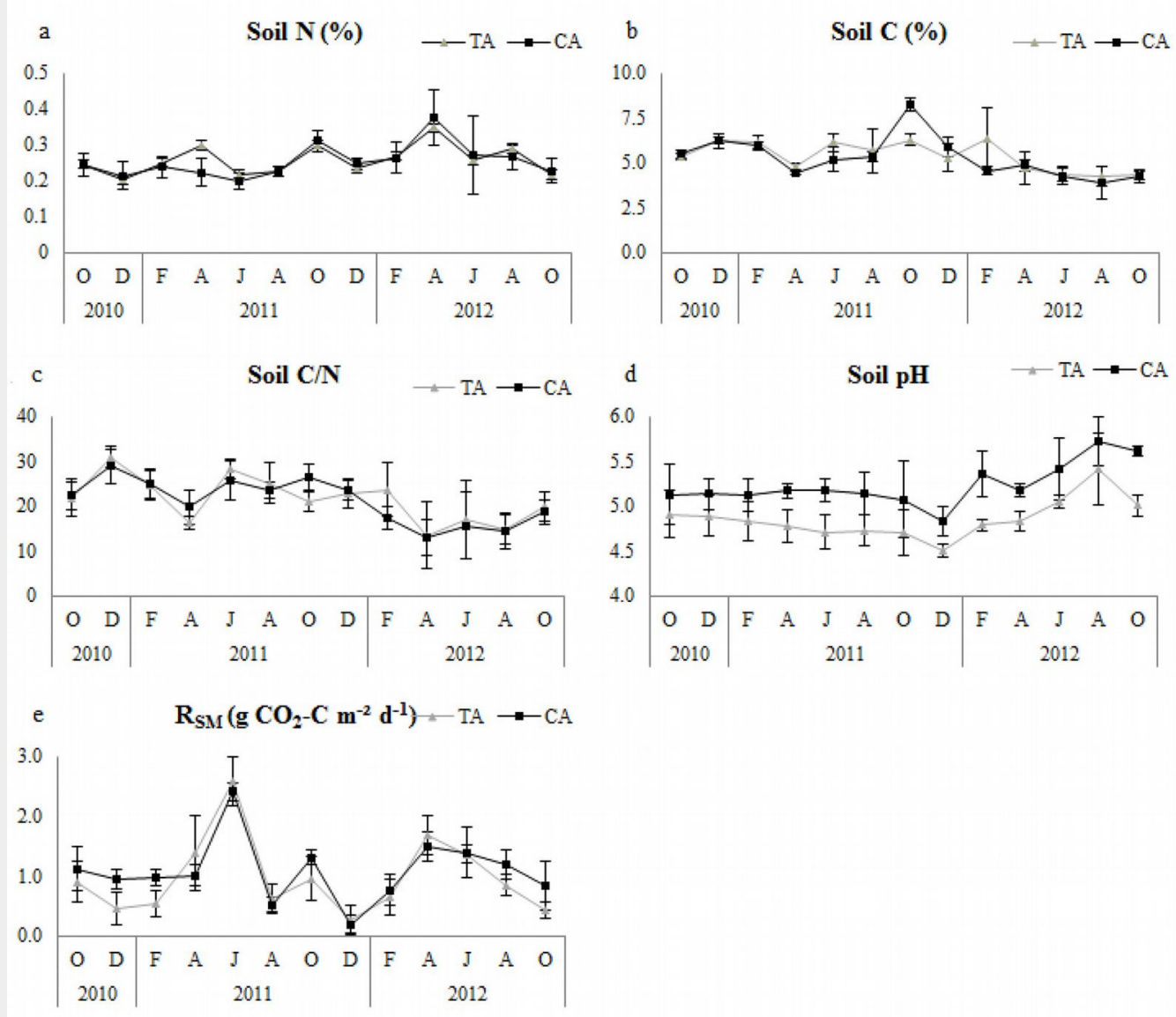

thinned plots, generally in the summer period from the beginning of April; moreover, it showed a parallel tendency on both thinned and control plots (Fig. 1). Similarly, GC showed similar temporal trends for thinned and control plots, and it was always higher in thinned plots (Fig. 1). Temporal variation of FF was always higher in control plots. $M_{s}$ did not show significant differences (Tab. 2), and it had similar temporal variation (Fig. 1) for both control and thinned plots. FRB showed seasonal fluctu- ations and was higher in thinned plots (Fig. not show statistically significant differ1). In summary, $T_{s}, F F, G C$ and FRB were sig- ences between control and thinned plots nificantly different between control and in any of the research periods (Tab. 2).

thinned plots over the first year, second Microbial respiration of forest floor year and 2-year study period (Tab. 2).

\section{Effects of thinning on $R_{S M}$ and $R_{F F M}$} ration $\left(R_{S M}\right)$ fluctuated similarly on both 3 ), and RFFM was $73 \%, 42 \%$ and $54 \%$ greater thinned $\left(0.25-2.22 \mathrm{~g} \mathrm{C} \mathrm{m}^{-2} \mathrm{~d}^{-1}\right)$ and control for control plots compared to thinned plots (0.16-2.12 $\left.\mathrm{g} \mathrm{C} \mathrm{m}^{-2} \mathrm{~d}^{-1}\right)$, and it mirrored plots for the first year, second year and the the temporal variation of $\mathrm{R}_{S}$ (Fig. 2). $\mathrm{R}_{\mathrm{SM}}$ did 2 -year study period, respectively (Tab. 2).
Fig. 3 - Temporal changes of forest floor microbial respiration $\left(R_{F F M}\right)$ and related variables in thinning and control plots. Error bars represent the standard deviation. (FF $\mathrm{N}$ ): forest floor nitrogen; (FF C): forest floor carbon; (TA): thinning area; (CA): control area.
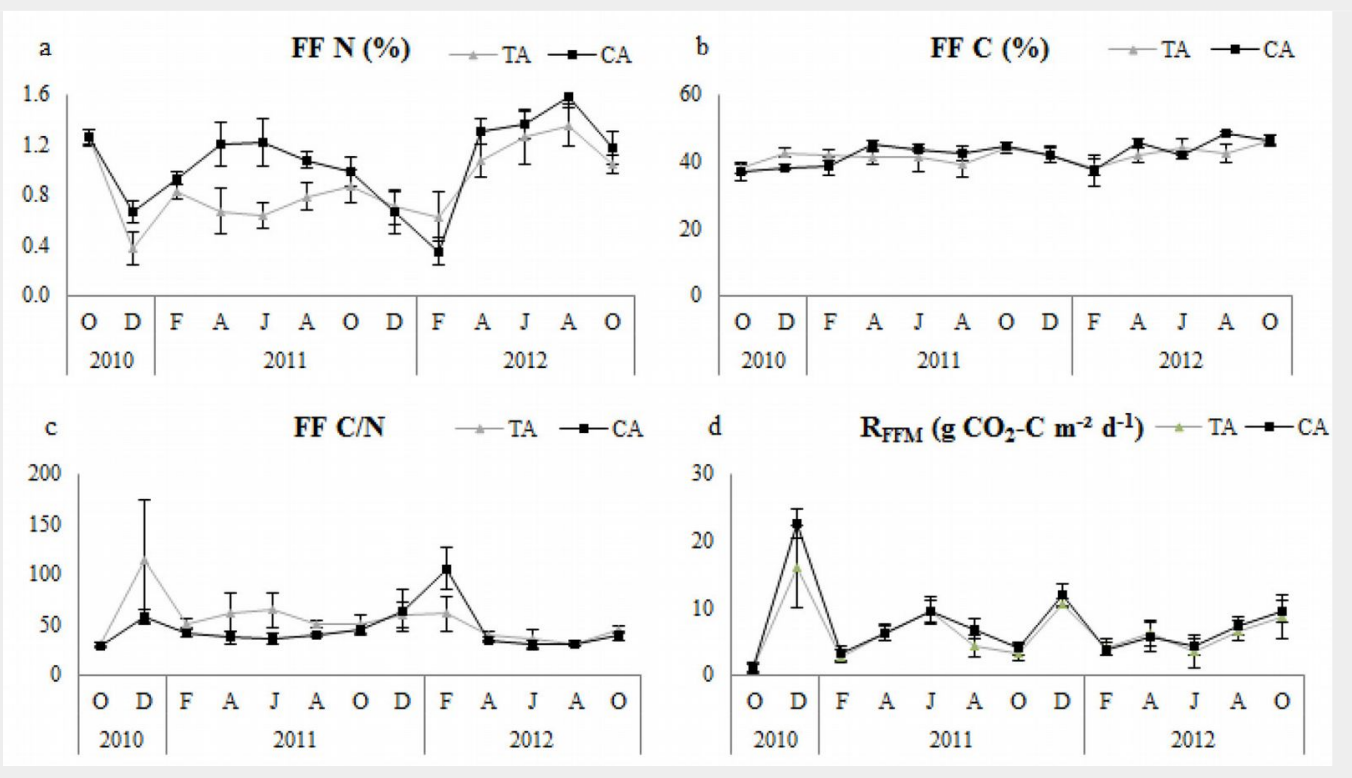
Soil $\mathrm{N}$, soil $\mathrm{C}$ and soil $\mathrm{C} / \mathrm{N}$ ratio were not significantly different between control and thinned plots in any of the research periods (Tab. 2). All plots had similar tendencies with regard to soil pH (Fig. 2), but it was significantly higher in control plots (Tab. 2). Control plots had significantly higher nitrogen concentration of forest floor (FFN) in all study periods, but forest floor carbon (FFC) did not differ significantly (Tab. 2); however, the forest floor $\mathrm{C} / \mathrm{N}$ ratio $(\mathrm{FFC} / \mathrm{N})$ was significantly higher in thinned plots (Tab. 2). Temporal variation of FFN and FFC/N showed similar tendencies, especially during the second year in all plots (Fig. 3).

Relationships between $R_{s}$ and variables In thinned plots, in general, $R_{s}$ was positively correlated with GC, $T_{S}$ and FRB during both the annual and 2-year study periods; however, significantly negative relationships were determined with $\mathrm{FF}$ for the 2-year research period and with $M_{s}$ in the first year and the 2-year research period (Tab. 3). In control plots, $R_{s}$ had a significantly linear correlation with GC in the first year and the 2-year research period, a significant correlation with $T_{s}$ for the first year only, and a negatively significant correlation with FF for the 2-year period. No significant correlation existed between $R_{s}$ and FRB in any of the research periods, and a significant correlation with $M_{s}$ was detected only for the second year (Tab. 3).

Relationships between $R_{S M}, R_{F F M}$ and variables

In thinned plots, $\mathrm{R}_{\mathrm{SM}}$ showed significant positive correlations with soil $\mathrm{pH}$ (except in the first year) and soil N. However, it had a significant and strong negative relationship with soil $\mathrm{C}$ and soil $\mathrm{C} / \mathrm{N}$ ratio for all research periods (Tab. 4). In control plots, $R_{S M}$ had a significant linear relationship with soil $\mathrm{N}$ and soil pH (except in the second year), and a significant negative correlation with soil $\mathrm{C}$ and soil $\mathrm{C} / \mathrm{N}$ ratio (except in the first year for both - Tab. 4).

$\mathrm{R}_{\mathrm{FFM}}$ showed a significant positive correlation with forest floor $\mathrm{C} / \mathrm{N}$ ratios and FFC (except in the first year) and a negative correlation with FFN in thinned plots for all research periods (Tab. 5). In control plots, $\mathrm{R}_{F F M}$ showed a significant linear relationship with FFC (except in the second year) and $\mathrm{C} / \mathrm{N}$ ratios of forest floor, and a significant negative correlation with FFN for all research periods (Tab. 5). Correlation results showed that changes in factors in the first year had a higher effect on the temporal variation of $R_{F F M}$ in the thinned and control plots.

\section{Discussion}

\section{Effects of thinning on $R_{S}$}

Thinning can affect the $R_{s}$ rate, which is an important determinant of soil carbon cycle and ecological factors such as root mass, root chemistry, soil moisture and soil

Tab. 3 - Correlation results of the soil respiration with related factors. (TA): thinning area; $(C A)$ : control area; $\left(T_{s}\right)$ : soil temperature; $\left(M_{s}\right)$ : soil moisture; $\left(R_{s}\right)$ : soil respiration; (FRB): fine root biomass; (GC): ground cover mass; (FF): forest floor mass; $\left({ }^{*}\right)$ : $p$ $<0.05 ;(* *): p<0.01$.

\begin{tabular}{lllccccc}
\hline Variable & Period & Plot & $\begin{array}{c}\mathrm{FF} \\
\left(\mathrm{g} \mathrm{m}^{-2}\right)\end{array}$ & $\begin{array}{c}\mathrm{GC} \\
\left(\mathrm{g} \mathrm{m}^{-2}\right)\end{array}$ & $\begin{array}{c}\mathrm{M}_{\mathrm{s}} \\
(\%)\end{array}$ & $\begin{array}{c}\mathrm{T}_{\mathrm{s}} \\
\left({ }^{\circ} \mathrm{C}\right)\end{array}$ & $\begin{array}{c}\mathrm{FRB} \\
\left(\mathrm{g} \mathrm{m}^{-2}\right)\end{array}$ \\
\hline $\mathrm{R}_{\mathrm{s}}$ & $2010-2011$ & TA & -0.219 & $0.461^{* *}$ & $-0.354^{* *}$ & $0.582^{* *}$ & $0.367^{* *}$ \\
$\left(\mathrm{~g} \mathrm{C} \mathrm{m}^{-2} \mathrm{~d}^{-1}\right)$ & & CA & -0.200 & $0.356^{* *}$ & -0.160 & $0.386^{* *}$ & 0.183 \\
& $2011-2012$ & TA & -0.200 & $0.531^{* *}$ & 0.030 & $0.437^{* *}$ & $0.295^{*}$ \\
& & CA & 0.004 & 0.178 & $0.497^{* *}$ & -0.144 & -0.109 \\
& $2010-2012$ & TA & $-0.206^{*}$ & $0.434^{* *}$ & $-0.203^{*}$ & $0.505^{* *}$ & $0.272^{* *}$ \\
& & CA & $-0.153^{*}$ & $0.228^{*}$ & 0.146 & 0.090 & 0.034 \\
\hline
\end{tabular}

Tab. 4 - Correlation results of the microbial soil respiration with related factors. (TA): thinning area; $(C A)$ : control area ; $\left(R_{S M}\right)$ : soil microbial respiration; $(C)$ : soil carbon; $(N)$ : soil nitrogen; $(*): p<0.05 ;(* *): p<0.01$.

\begin{tabular}{|c|c|c|c|c|c|c|}
\hline Variable & Period & Plot & $\mathrm{pH}$ & C (\%) & $\mathrm{C} / \mathrm{N}$ & $\mathrm{N}(\%)$ \\
\hline \multirow{6}{*}{$\begin{array}{l}R_{S M} \\
\left(g^{\prime} C m^{-2} d^{-1}\right)\end{array}$} & $2010-2011$ & TA & 0.099 & $-0.729^{* *}$ & -0.784 & $0.683^{* * *}$ \\
\hline & & CA & $0.379^{* * *}$ & 0.213 & -0.076 & $0.261^{*}$ \\
\hline & $2011-2012$ & TA & $0.314^{* *}$ & $-0.392^{* *}$ & $-0.508^{* *}$ & $0.621^{\text {t* }}$ \\
\hline & & CA & 0.161 & $-0.418 *$ & $-0.554^{* *}$ & $0.418^{* *}$ \\
\hline & $2010-2012$ & TA & $0.319^{* *}$ & $-0.551^{* *}$ & -0.596 & 0.616 \\
\hline & & CA & $0.284^{* *}$ & $-0.291^{* *}$ & $-0.499^{* *}$ & $0.429^{* *}$ \\
\hline
\end{tabular}

Tab. 5 - Correlation results of the microbial forest floor respiration with related factors. (TA): thinning area; $(C A)$ : control area; $\left(R_{F F M}\right)$ : forest floor microbial respiration; (FFC): forest floor carbon; (FFN): forest floor nitrogen; $(*): p<0.05 ;(* *): p<0.01$.

\begin{tabular}{llllll}
\hline Variable & Period & Plot & FFC \% & FFN \% & C/N \\
\hline $\mathrm{R}_{\text {FFM }}$ & $2010-2011$ & TA & 0.148 & $-0.716^{* *}$ & $0.763^{* *}$ \\
$\left(\mathrm{~g} \mathrm{C} \mathrm{m}^{-2} \mathrm{~d}^{-1}\right)$ & & CA & $0.388^{* *}$ & $-0.739^{* *}$ & $0.759^{* * *}$ \\
& $2011-2012$ & TA & $0.415^{* *}$ & $-0.302^{*}$ & $0.279^{*}$ \\
& & CA & 0.213 & $-0.271^{*}$ & $0.479^{* *}$ \\
& $2010-2012$ & TA & $0.292^{* *}$ & $-0.502^{* *}$ & $0.561^{* *}$ \\
& & CA & $0.236^{* *}$ & $-0.298^{* *}$ & $0.416^{* *}$ \\
\hline
\end{tabular}

temperature (Burton et al. 2002, Ryu et al. 2009). The mean annual $R_{S}$ in this study was significantly higher in the thinned plots compared to the control plots only in the first year. The $R_{s}$ rates did not differ significantly in either the second year or throughout the 2-year study period. These results were consistent with those of several previous research studies. For example, Vesala et al. (2005) and Campbell et al. (2009) reported that thinning did not greatly affect soil respiration. In addition, Tian et al. (2010) found that soil respiration increased quickly in the first period after thinning and declined afterward.

In our study, of all factors evaluated, GC and $T_{s}$ had the greatest positive influence on $R_{S}$ following FRB. Similarly, Liang et al. (2012) reported that the understory plant biomass strongly controlled the soil $\mathrm{CO}_{2}$ efflux owing to the root production in the thinned forest stands, which was consistent with previous studies (Selig \& Seiler 2004, Wiseman \& Seiler 2004, Grady \& Hart 2006, Laughlin et al. 2006, Moore et al. 2006). Ground cover species were not identified in the current study, however, the species makeup can influence soil respiration. For example, Dias et al. (2010) found a linear relationship between soil respiration and plant species diversity of ground cover. Further, Mäkiranta et al. (2008) detected a positive correlation between ground cover biomass and respiration. Nevertheless, the role of ground cover is rarely considered in the analysis of carbon balance in forest ecosystems (Goulden \& Crill 1997, Law et al. 1999, Kolari et al. 2006), and it is essential to understand the effects of thinning on Rs when evaluating the reaction of undergrowth vegetation (Liang et al. 2012).

Soil temperature and moisture significantly affect soil respiration. We found that thinning positively affected soil temperature in all research periods, while the relationship of soil moisture with $R_{s}$ was significantly negative in the first year and over the two-year research period in the thinned plots. Our findings are consistent with those of Graf et al. (2012) and Joo et al. (2012), who found that soil respiration was strongly correlated with soil temperature. However, Sullivan et al. (2008) reported that soil temperature did not differ significantly between the thinned plots and the control sites, suggesting that thinning did not alter soil $\mathrm{CO}_{2}$ efflux because of soil tem- 
perature variation, though it might change the soil physical environment. Nevertheless, several researchers have stated that soil temperature is a key component in estimating the $\mathrm{CO}_{2}$ flux from forest soils (Keith et al. 1997, Londo et al. 1999, Parkin \& Kaspar 2003, Conant et al. 2004, Lee et al. 2005, Tang et al. 2005, Graf et al. 2012, Olajuyigbe et al. 2012). It has also been noted that thinning increases canopy opening, which in turn increases the amount of sunlight reaching the forest floor (Ryu et al. 2009).

Thinning can change tree biomass and root density. In the present study, fine root biomass was significantly higher in the thinned plots. Our results disagree with previous studies that demonstrated a reduction in fine root biomass after thinning (Silver \& Vogt 1993, Lindo \& Visser 2003, Tufekcioglu et al. 2005, Ryu et al. 2009, Olajuyigbe et al. 2012, Pang et al. 2013). The main reason that fine root biomass was higher in the thinned plots is probably related to the increased ground cover biomass after the thinning treatment.

Decomposition occurring in the forest floor can support soil respiration for a short period of time (Son et al. 2004, Misson et al. 2005, Sullivan et al. 2008, Olajuyigbe et al. 2012). Our results for all study periods demonstrate that the forest floor mass was significantly higher in the control plots, most likely because of the decreased tree density and reduced litter fall contribution to forest floor in the thinned plots or because of increased decomposition. Similar to our results, Makineci (2005) found less forest floor litter after thinning. Furthermore, the negative relationship between $F F$ and $R_{S}$ in the 2-year period in both the thinned and control plots suggest that soil respiration increased owing to the decreased FF mass. However, Luo \& Zhou (2006) reported that decreased FF mass caused by decomposition and thinning might increase soil respiration because of the reduced resistance of $\mathrm{CO}_{2}$ diffusion on the soil surface.

\section{Thinning effects on $R_{S M}$ and $R_{F F M}$}

We did not find significant differences in $R_{S M}$ between the thinned and control plots. This result suggests that soil microbial activity and respiration did not change after thinning. This interpretation is supported by soil carbon and nitrogen concentrations not being significantly different between the thinned and control plots. Similarly, Son et al. (2004) found no significant differences in microbial activity during decomposition among plots with different thinning intensities. In contrast, Giai \& Boerner (2007) found higher microbial activity in thinned plots compared to control plots. Despite the non-significant changes between the thinning treatment and the control, $R_{S M}$ of thinned plots usually had strong positive correlations with soil $\mathrm{pH}$ and soil nitrogen concentration, and strong negative correlations with soil carbon concentration and soil $\mathrm{C} / \mathrm{N}$ ratio. Several authors have stated that soil microbial respiration is linearly correlated with both soil carbon and nitrogen concentrations (Mariani et al. 2006, Traoré et al. 2007, Ananyeva et al. 2008). In this context, Luo \& Zhou (2006) reported that a positive correlation exists between the mineralized nitrogen ratio and microbial respiration because of the binding of mineralized nitrogen with carbon during the microbial decomposition of soil organic matter. However, Rodeghiero \& Cescatti (2006) found that microbial respiration decreased as the soil nitrogen concentration increased.

$R_{F F M}$ of thinned plots was significantly lower than that of the control for all research periods. This finding may be associated with the decreased microbial activity and respiration of forest floor in the thinned areas due to the environmental changes. Consistent with our study, Lindo \& Visser (2003) found that forest floor microbial respiration decreased considerably after thinning treatments. Microbial respiration in forest floor had a statistically significant and strong positive correlation with carbon concentration and $\mathrm{C} / \mathrm{N}$ ratio of forest floor and a significantly negative correlation with nitrogen concentration. Microorganisms consume carbohydrate and protein-based compounds as nutrients (Lavelle \& Spain 2001, Lützow et al. 2006), and our results might also be interpreted as indicating increased microbial consumption of protein-based (nitrogen) and sugarbased (carbohydrate) compounds in soil and forest floor.

\section{Conclusions}

Determining soil respiration is important because it has in general a positive relationship with net ecosystem productivity. Higher $R_{S}$ rates in thinned plots are therefore important for net ecosystem productivity. In this study, ground cover mass and soil temperature were found to have the largest effects on $R_{s}$ among the investigated factors. In this context, a specific evaluation of ground cover (species composition or cover degree) may clarify such effects in future studies. $R_{S M}$ did not differ significantly among plots, although it was higher in the thinned plots over the study period. In contrast, microbial respiration in forest floor was higher in the control plots than in the thinned plots. In a similar study (Akburak \& Makineci 2015) with the same thinning intensity in a neighboring stand of Hungarian oak (Quercus frainetto Ten.), we obtained results that differed from the findings of the present study, which suggests that thinning might yield species-specific outcomes.

\section{Acknowledgements}

This paper reports part of the results from the PhD thesis of Serdar Akburak under the supervision of Ender Makineci completed in 2013 at the Science Institute,
Istanbul University, Turkey. This work was supported by the Scientific Research Projects Coordination Unit of Istanbul University, Project numbers: 9652 and UDP51525. It was presented as a poster presentation titled "Thinning effects on soil and microbial respiration of forest floor and soil in European hornbeam (Carpinus betulus L.) forest in Istanbul - Turkey", and its abstract was published in the abstracts book of the Conference "Coppice 2015Coppice Forests: Past, Present and Future" in Brno, Czech Republic, 9-11 April 2015.

\section{References}

Akburak S (2013). The effects of thinning on soil respiration and microbial respiration in oak and hornbeam stands. PhD thesis, Science Institute, Istanbul University, Istanbul, Turkey, pp. 39-52. [in Turkish with English summary]

Akburak S, Makineci E (2015). Effects of thinning on soil respiration and microbial respiration of forest floor and soil in an oak (Quercus frainetto) forest. Soil Research 53 (5): 522-530. doi: 10.1071/SR14309

Alef K, Nannipieri P (1995). Estimation of microbial activites. In: "Methods in applied soil microbiology and biochemistry". Academic press, San Diego, CA, USA, pp. 214-216.

Alvarez S, Ortiz C, Díaz-Pinés E, Rubio A (2014). Influence of tree species composition, thinning intensity and climate change on carbon sequestration in Mediterranean mountain forests: a case study using the $\mathrm{CO}_{2}$ Fix model. Mitigation and Adaptation Strategies for Global Change: 114. - doi: 10.1007/s11027-014-9565-4

Ananyeva ND, Susyan EA, Chernova OV, Wirth S (2008). Microbial respiration activities of soils from different climatic regions of European Russia. European Journal of Soil Biology 44 (2): 147-157. - doi: 10.1016/j.ejsobi.2007.05.002

Burton A, Pregitzer K, Ruess R, Hendrick R, Allen $M$ (2002). Root respiration in North American forests: effects of nitrogen concentration and temperature across biomes. Oecologia 131 (4): 559-568. - doi: 10.1007/s00442-002-0931-7 Campbell J, Alberti G, Martin J, Law B (2009). Carbon dynamics of a ponderosa pine plantation following a thinning treatment in the northern Sierra Nevada. Forest Ecology and Management 257 (2): 453-463. - doi: 10.1016/j. foreco.2008.09.021

Campbell JL, Harmon ME, Mitchell SR (2012). Can fuel-reduction treatments really increase forest carbon storage in the western US by reducing future fire emissions? Frontiers in Ecology and the Environment 10 (2): 83-90. - doi: 10.1890/ 110057

Cheng X, Han H, Kang F, Liu K, Song Y, Zhou B, Li $Y$ (2014). Short-term effects of thinning on soil respiration in a pine (Pinus tabulaeformis) plantation. Biology and Fertility of Soils 50 (2): 357367. - doi: 10.1007/s00374-013-0852-0

Conant RT, Dalla-Betta P, Klopatek CC, Klopatek JM (2004). Controls on soil respiration in semiarid soils. Soil Biology and Biochemistry 36 (6): 945-951. - doi: 10.1016/j.soilbio.2004.02.013

Dias ATC, Van Ruijven J, Berendse F (2010). Plant species richness regulates soil respiration through changes in productivity. Oecologia 163 (3): 805-813. - doi: 10.1007/s00442-010-1569-5 
Dore S, Montes Helu M, Hart SC, Hungate BA, Koch GW, Moon JB, Finkral AJ, Kolb TE (2012). Recovery of ponderosa pine ecosystem carbon and water fluxes from thinning and stand' $€$ replacing fire. Global Change Biology 18 (10): 3171-3185. - doi: 10.1111/j.1365-2486.2012.02775.x Fu X, Shao M, Wei X, Wang H (2013). Soil respiration as affected by vegetation types in a semiarid region of China. Soil Science and Plant Nutrition 59 (5): 715-726. - doi: 10.1080/00380 768.2013.821935

Giai C, Boerner REJ (2007). Effects of ecological restoration on microbial activity, microbial functional diversity, and soil organic matter in mixed-oak forests of southern Ohio, USA. Applied Soil Ecology 35 (2): 281-290. - doi: 10.1016/j. apsoil.2006.08.003

Gong J-R, Wang Y, Liu M, Huang Y, Yan X, Zhang Z, Zhang W (2014). Effects of land use on soil respiration in the temperate steppe of Inner Mongolia, China. Soil and Tillage Research 144: 20-31. - doi: 10.1016/j.still.2014.06.002

Goulden ML, Crill PM (1997). Automated measurements of $\mathrm{CO}_{2}$ exchange at the moss surface of a black spruce forest. Tree Physiology 17 (8-9): 537-542. - doi: 10.1093/treephys/17.8-9.537 Grady KC, Hart SC (2006). Influences of thinning, prescribed burning, and wildfire on soil processes and properties in southwestern ponderosa pine forests: a retrospective study. Forest Ecology and Management 234 (1): 123-135. doi: 10.1016/j.foreco.2006.06.031

Graf A, Herbst M, Weihermüller L, Huisman JA, Prolingheuer $\mathrm{N}$, Bornemann L, Vereecken $\mathrm{H}$ (2012). Analyzing spatiotemporal variability of heterotrophic soil respiration at the field scale using orthogonal functions. Geoderma 181-182: 91-101. - doi: 10.1016/j.geoderma.2012.02.016 IUSS Working Group WRB (2006). World reference base for soil resources 2006. World Soil Resources Reports 103, FAO, Rome, Italy, pp. 145.

Joo SJ, Park SU, Park MS, Lee CS (2012). Estimation of soil respiration using automated chamber systems in an oak (Quercus mongolica) forest at the Nam-San site in Seoul, Korea. The Science of the Total Environment 416: 400-409. doi: 10.1016/j.scitotenv.2011.11.025

Keith H, Jacobsen K, Raison R (1997). Effects of soil phosphorus availability, temperature and moisture on soil respiration in Eucalyptus pauciflora forest. Plant and Soil 190 (1): 127-141. - doi: 10.1023/A:1004279300622

Kolari P, Pumpanen J, Kulmala L, Ilvesniemi $\mathrm{H}$, Nikinmaa E, Grönholm T, Hari P (2006). Forest floor vegetation plays an important role in photosynthetic production of boreal forests. Forest Ecology and Management 221 (1): 241-248. doi: 10.1016/j.foreco.2005.10.021

Laughlin DC, Moore MM, Bakker JD, Casey CA, Springer JD, Fulé PZ, Covington WW (2006). Assessing targets for the restoration of herbaceous vegetation in ponderosa pine forests. Restoration Ecology 14 (4): 548-560. - doi: 10.1111/j.1526-100X.2006.00166.x

Lavelle P, Spain AV (2001). Soil organisms. In: "Soil ecology". Springer, Netherlands, pp. 211. doi: 10.1007/0-306-48162-6_3

Law BE, Baldocchi DD, Anthoni PM (1999). Below-canopy and soil $\mathrm{CO}_{2}$ fluxes in a ponderosa pine forest. Agricultural and Forest Meteorol- ogy 94 (3): 171-188. - doi: 10.1016/S0168-1923(99) 00019-2

Lee M-S, Nakane K, Nakatsubo T, Koizumi H (2005). The importance of root respiration in annual soil carbon fluxes in a cool-temperate deciduous forest. Agricultural and Forest Meteorology 134 (1): 95-101. - doi: 10.1016/j.agrfor met.2005.08.011

Liang F, Ma L, Jia Z, Wang X, You W, Wang W, Wang $K$ (2012). Aboveground and root carbon stocks for Chinese arborvitae plantation following different silvicultural thinning. Energy Procedia 14: 913-918. - doi: 10.1016/j.egypro.2011.12. 1032

Lindo Z, Visser S (2003). Microbial biomass, nitrogen and phosphorus mineralization, and mesofauna in boreal conifer and deciduous forest floors following partial and clear-cut harvesting. Canadian Journal of Forest Research 33 (9): 1610-1620. - doi: 10.1139/x03-080

Londo A, Messina M, Schoenholtz S (1999). Forest harvesting effects on soil temperature, moisture, and respiration in a bottomland hardwood forest. Soil Science Society of America Journal 63 (3): 637-644. - doi: 10.2136/sssaj1999. $03615995006300030029 x$

Luo Y, Zhou X (2006). Soil respiration and the environment. Academic press, San Diego, CA, USA. pp. 328.

Lützow MV, Kögel KL, Ekschmitt K, Matzner E, Guggenberger G, Marschner B, Flessa H (2006). Stabilization of organic matter in temperate soils: mechanisms and their relevance under different soil conditions-a review. European Journal of Soil Science 57 (4): 426-445. - doi: 10.1111/j.1365-2389.2006.00809.x

Makineci $E$ (2005). Long term effects of thinning on soil and forest floor in a sessile oak (Quercus petreae (Matlusch) Lieb.) Forest. Journal of Environmental Biology 26 (2): 257-263. [online] URL: http://europepmc.org/abstract/med/16161 982

Makineci E, Ozdemir E, Caliskan S, Yilmaz E, Kumbasli M, Keten A, Beskardes V, Zengin $\mathrm{H}$, Yilmaz H (2015). Ecosystem carbon pools of coppice-originated oak forests at different development stages. European Journal of Forest Research 134 (2): 319-333. - doi: 10.1007/ s10342-014-0854-y

Mäkiranta P, Minkkinen K, Hytönen J, Laine J (2008). Factors causing temporal and spatial variation in heterotrophic and rhizospheric components of soil respiration in afforested organic soil croplands in Finland. Soil Biology and Biochemistry 40 (7): 1592-1600. - doi: 10.1016/j.soilbio.2008.01.009

Mariani L, Chang SX, Kabzems R (2006). Effects of tree harvesting, forest floor removal, and compaction on soil microbial biomass, microbial respiration, and $\mathrm{N}$ availability in a boreal aspen forest in British Columbia. Soil Biology and Biochemistry 38 (7): 1734-1744. - doi: 10.1016/j.soilbio.2005.11.029

Misson L, Tang J, Xu M, McKay M, Goldstein A (2005). Influences of recovery from clear-cut, climate variability, and thinning on the carbon balance of a young ponderosa pine plantation. Agricultural and Forest Meteorology 130 (3): 207-222. - doi: 10.1016/j.agrformet.2005.04.001 Moore MM, Casey CA, Bakker JD, Springer JD, Fulé PZ, Covington WW, Laughlin DC (2006).
Herbaceous vegetation responses (1992-2004) to restoration treatments in a ponderosa pine forest. Rangeland Ecology and Management 59 (2): 135-144. - doi: 10.2111/05-051R2.1

OGM (2014). Forests of Turkey. Turkish Ministry of Forest and Water Affairs, General Directorate of Forestry, Ankara, Turkey, pp. 25. [in Turkish]

Olajuyigbe S, Tobin B, Saunders M, Nieuwenhuis $M$ (2012). Forest thinning and soil respiration in a Sitka spruce forest in Ireland. Agricultural and Forest Meteorology 157: 86-95. - doi: 10.1016/j. agrformet.2012.01.016

Pang X, Bao W, Zhu B, Cheng W (2013). Responses of soil respiration and its temperature sensitivity to thinning in a pine plantation. Agricultural and Forest Meteorology 171: 57-64. doi: 10.1016/j.agrformet.2012.12.001

Parkin TB, Kaspar TC (2003). Temperature controls on diurnal carbon dioxide flux. Soil Science Society of America Journal 67 (6): 17631772. - doi: 10.2136/sssaj2003.1763

Rodeghiero M, Cescatti A (2006). Indirect partitioning of soil respiration in a series of evergreen forest ecosystems. Plant and Soil 284 (12): 7-22. - doi: 10.1007/s11104-005-5109-8

Ryu SR, Concilio A, Chen J, North M, Ma S (2009). Prescribed burning and mechanical thinning effects on belowground conditions and soil respiration in a mixed-conifer forest, California. Forest Ecology and Management 257 (4): 1324-1332. - doi: 10.1016/j.foreco.2008.11.033 Selig $M$, Seiler J (2004). Soil $\mathrm{CO}_{2}$ efflux trends following the thinning of a 22-year-old loblolly pine plantation on the piedmont of Virginia. General Technical Report SRS-71, Southern Research Station, USDA Forest Service, Asheville, NC, USA, pp. 469-472. [online] URL: http:// www.treesearch.fs.fed.us/pubs/6740

Silver WL, Vogt KA (1993). Fine root dynamics following single and multiple disturbances in a subtropical wet forest ecosystem. The Journal of Ecology 81 (4): 729. - doi: 10.2307/2261670

Son Y, Jun YC, Lee YY, Kim RH, Yang SY (2004). Soil carbon dioxide evolution, litter decomposition, and nitrogen availability four years after thinning in a Japanese larch plantation. Communications in Soil Science and Plant Analysis 35 (7-8): 1111-1122. - doi: 10.1081/CSS-120030593 Sullivan B, Kolb T, Hart S, Kaye J, Dore S, Montes-Helu M (2008). Thinning reduces soil carbon dioxide but not methane flux from southwestern USA ponderosa pine forests. Forest Ecology and Management 255 (12): 4047-4055. doi: 10.1016/j.foreco.2008.03.051

Tang J, Qi Y, Xu M, Misson L, Goldstein $\mathrm{AH}$ (2005). Forest thinning and soil respiration in a ponderosa pine plantation in the Sierra $\mathrm{Ne}$ vada. Tree Physiology 25 (1): 57-66. - doi: 10.1093/treephys/25.1.57

Tian D-L, Peng Y-Y, Yan W-D, Fang X, Kang W-X, Wang G-J, Chen X-Y (2010). Effects of thinning and litter fall removal on fine root production and soil organic carbon content in Masson pine plantations. Pedosphere 20 (4): 486-493. - doi: 10.1016/S1002-0160(10)60038-0

Traoré S, Thiombiano L, Millogo JR, Guinko S (2007). Carbon and nitrogen enhancement in Cambisols and Vertisols by Acacia spp. in eastern Burkina Faso: relation to soil respiration and microbial biomass. Applied Soil Ecology 35 
(3): 660-669. - doi: 10.1016/j.apsoil.2006.09.004 Tufekcioglu A, Raich J, Isenhart T, Schultz R (2003). Biomass, carbon and nitrogen dynamics of multi-species riparian buffers within an agricultural watershed in Iowa, USA. Agroforestry Systems 57 (3): 187-198. - doi: 10.1023/A:102489 8615284

Tufekcioglu A, Guner S, Tilki F (2005). Thinning effects on production, root biomass and some soil properties in a young oriental beech stand in Artvin, Turkey. Journal of environmental biology/Academy of Environmental Biology, India
26 (1): 91-95. [online] URL: http://openaccess. artvin.edu.tr/jspui/handle/11494/554

Vesala T, Suni T, Rannik U, Keronen P, Markkanen T, Sevanto S, Grönholm T, Smolander S, Kulmala $M$, Ilvesniemi $H$, Ojansuu $R$, Uotila $A$, Levula J, Mäkelä A, Pumpanen J, Kolari P, Kulmala L, Altimir N, Berninger F, Nikinmaa E, Hari $P$ (2005). Effect of thinning on surface fluxes in a boreal forest. Global Biogeochemical Cycles 19 (2): 1-11. - doi: 10.1029/2004GB002316

Wiseman PE, Seiler JR (2004). Soil $\mathrm{CO}_{2}$ efflux across four age classes of plantation loblolly pine (Pinus taeda L.) on the Virginia Piedmont. Forest Ecology and Management 192 (2): 297311. - doi: 10.1016/j.foreco.2004.01.017

Wu Z, Guan L, Chen B, Yang C, Lan G, Xie G, Zhou $Z$ (2013). Components of soil respiration and its monthly dynamics in rubber plantation ecosys tems. In: Proceedings of the " 4 th International Conference on Digital Manufacturing and Automation" (ICDMA). Qingdao (China), 29-30 Jun 2013. IEEE, pp. 361-369. - doi: 10.1109/ICDMA.20 13.404 